\title{
DOE-HTGR-88147
}

Revision 0
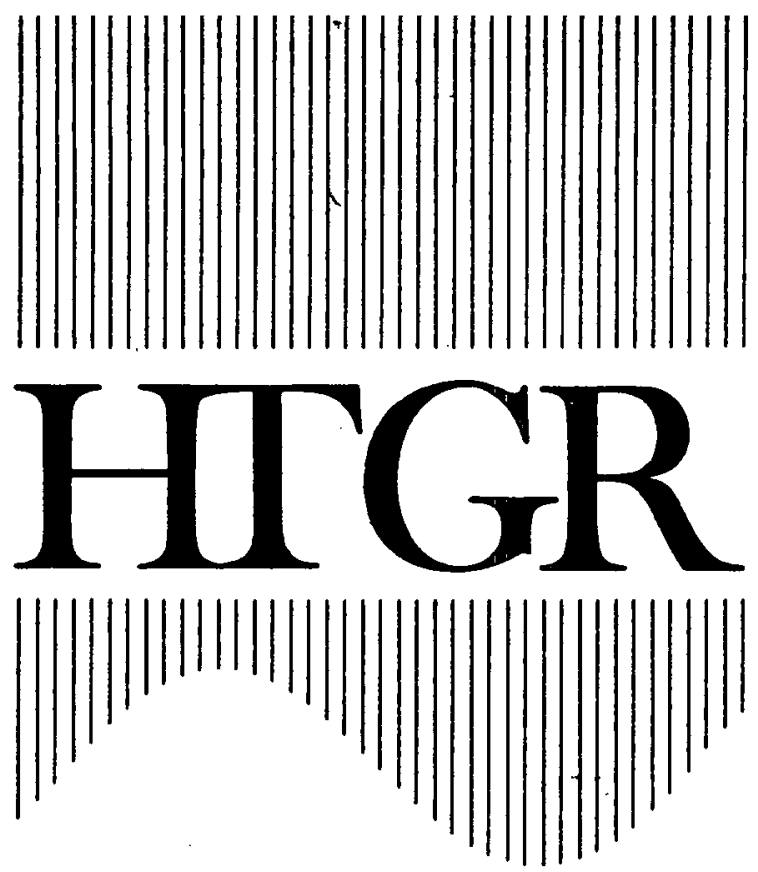

\section{MULTIAXIAL GRAPHITE TEST SPECIMEN}

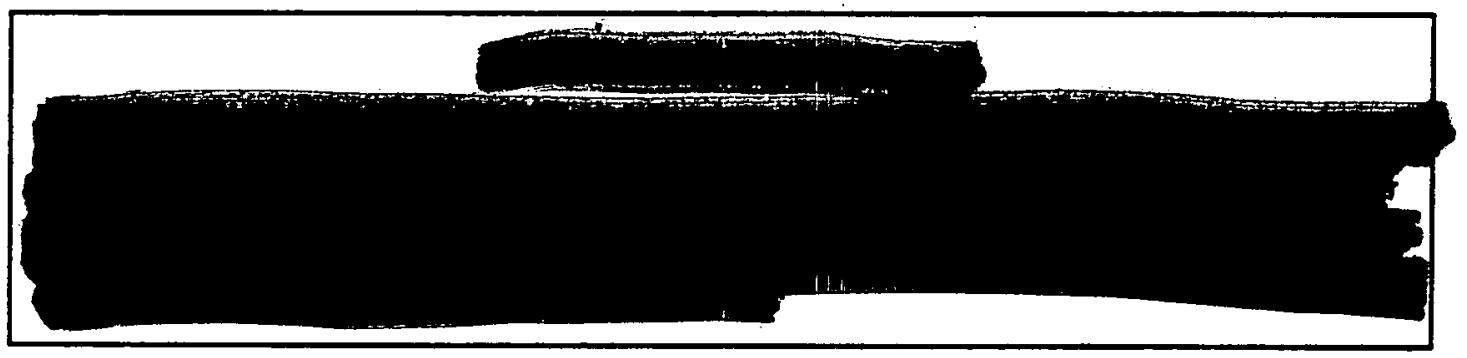

\section{AUTHORS/CONTRACTORS}

GENERAL ATOMICS
DISTRIBUTION OF THIS DOCUMENT IS UNLIMTTED

This document is PUBLICLY RELEASABLE

per memo-David A. STeinman, General PeR memo-David A. Classirication OfFicer, $1 / 22 / 01$
Atomics
HeleN allen

ISSUED BY GENERAL ATOMICS FOR THE DEPARTMENT OF ENERGY CONTRACT DE-ACO3-88SF17367 


\section{DISCLAIMER}

This report was prepared as an account of work sponsored by the United States Government. Neither the United States nor the United States Department of Energy, nor any of their employees, makes any warranty, express or implied, or assumes any legal liability or responsibility for the accuracy, completeness, or usefulness of any information, apparatus, product, or process disclosed, or represents that its use would not infringe privately owned rights. Reference herein to any specific commercial product, process, or service by trade name, mark, manufacturer, or otherwise, does not necessarily constitute or imply its endorsement, recommendation, or favoring by the United States Government or any agency thereof. The views and opinions of authors expressed herein do not necessarily state or reflect those of the United States Government or any agency thereof. 


\section{DISCLAIMER}

This report was prepared as an account of work sponsored by an agency of the United States Government. Neither the United States Government nor any agency Thereof, nor any of their employees, makes any warranty, express or implied, or assumes any legal liability or responsibility for the accuracy, completeness, or usefulness of any information, apparatus, product, or process disclosed, or represents that its use would not infringe privately owned rights. Reference herein to any specific commercial product, process, or service by trade name, trademark, manufacturer, or otherwise does not necessarily constitute or imply its endorsement, recommendation, or favoring by the United States Government or any agency thereof. The views and opinions of authors expressed herein do not necessarily state or reflect those of the United States Government or any agency thereof. 


\section{DISCLAIMER}

Portions of this document may be illegible in electronic image products. Images are produced from the best available original document. 


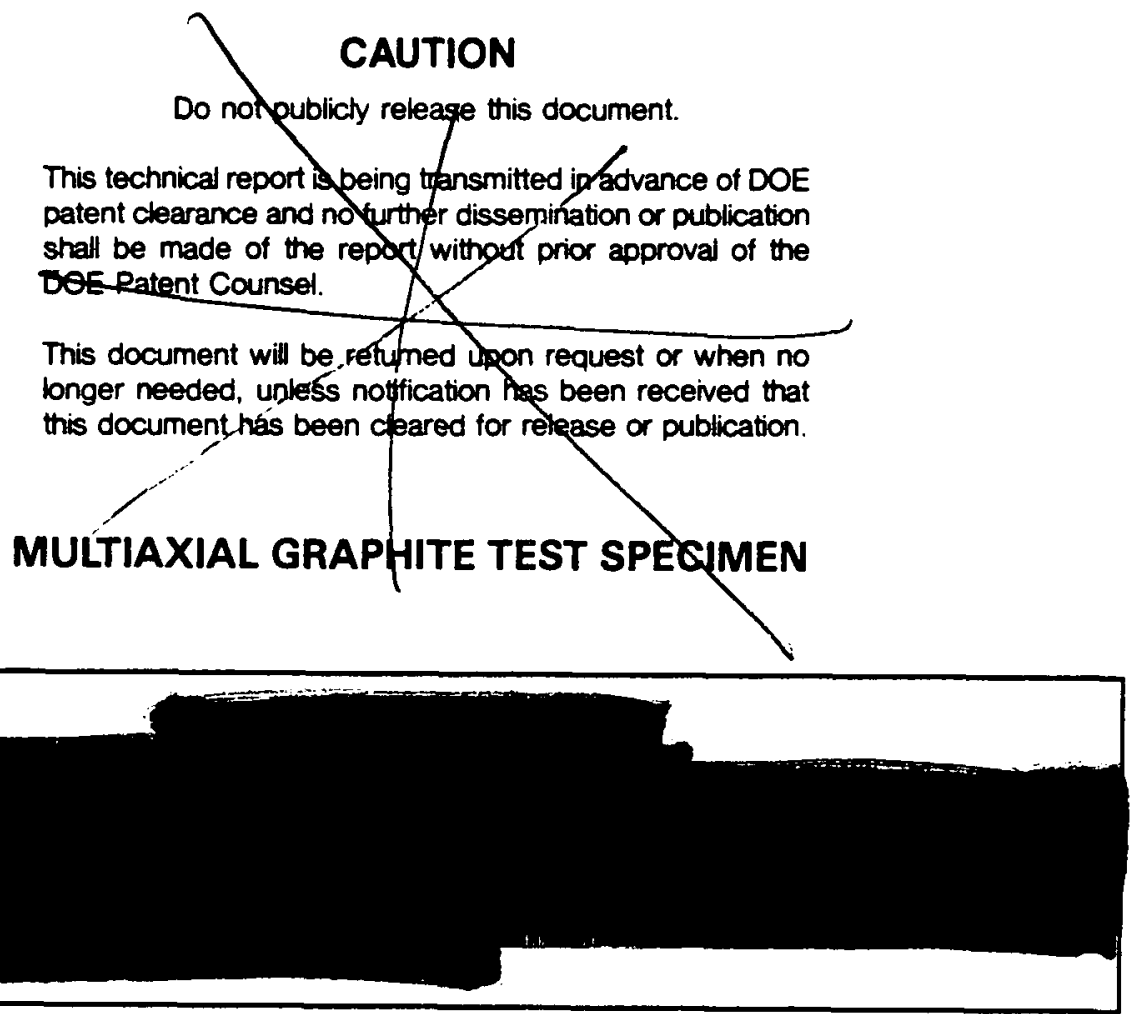

\title{
DISTRIBUTION OF THIS DOCUMENT IS UNLIMITED
}

This dosument is

PUBLICLY RELEASABLE

$$
\begin{aligned}
& \text { per memo- David a. Stoinman geveral } \\
& \text { per memo-Davida Sto inman Geveral } \\
& \text { ATOMiCS ClASSIFiCATION Helon AlkN }
\end{aligned}
$$

\author{
Issued By: \\ General Atomics \\ P.O. Box 85608 \\ San Diego, California 92138-5608 \\ DOE CONTRACT DE-AC03-88SF17367 \\ GA Project 6300 \\ SEPTEMBER 1988
}


ISSUE SUMMARY

\begin{tabular}{|lll}
\hline TITLE Multiaxial Graphite Test Specimen & $\square$ R \& & APPROVAL LEVEL \\
& & OV \& S \\
& & OESIGN
\end{tabular}

2

\begin{tabular}{|l|l|l|l|l}
\hline DISCIPLINE & SYSTEM & DOC. TYPE & PROJECT & DOCUMENT NO.
\end{tabular}

\begin{tabular}{l|l|l|l|l}
$S$ & 11 & RGE & 6300 & DOE-HTGR-88147
\end{tabular}

ISSUE NO./LTR.

0

\begin{tabular}{|l|l|l}
\hline QUALITY ASSURANCE LEVEL & SAFETY CLASSIFICATION & SEISMIC CATEGORY
\end{tabular} N/A

N/A

$\mathrm{N} / \mathrm{A}$

N/A

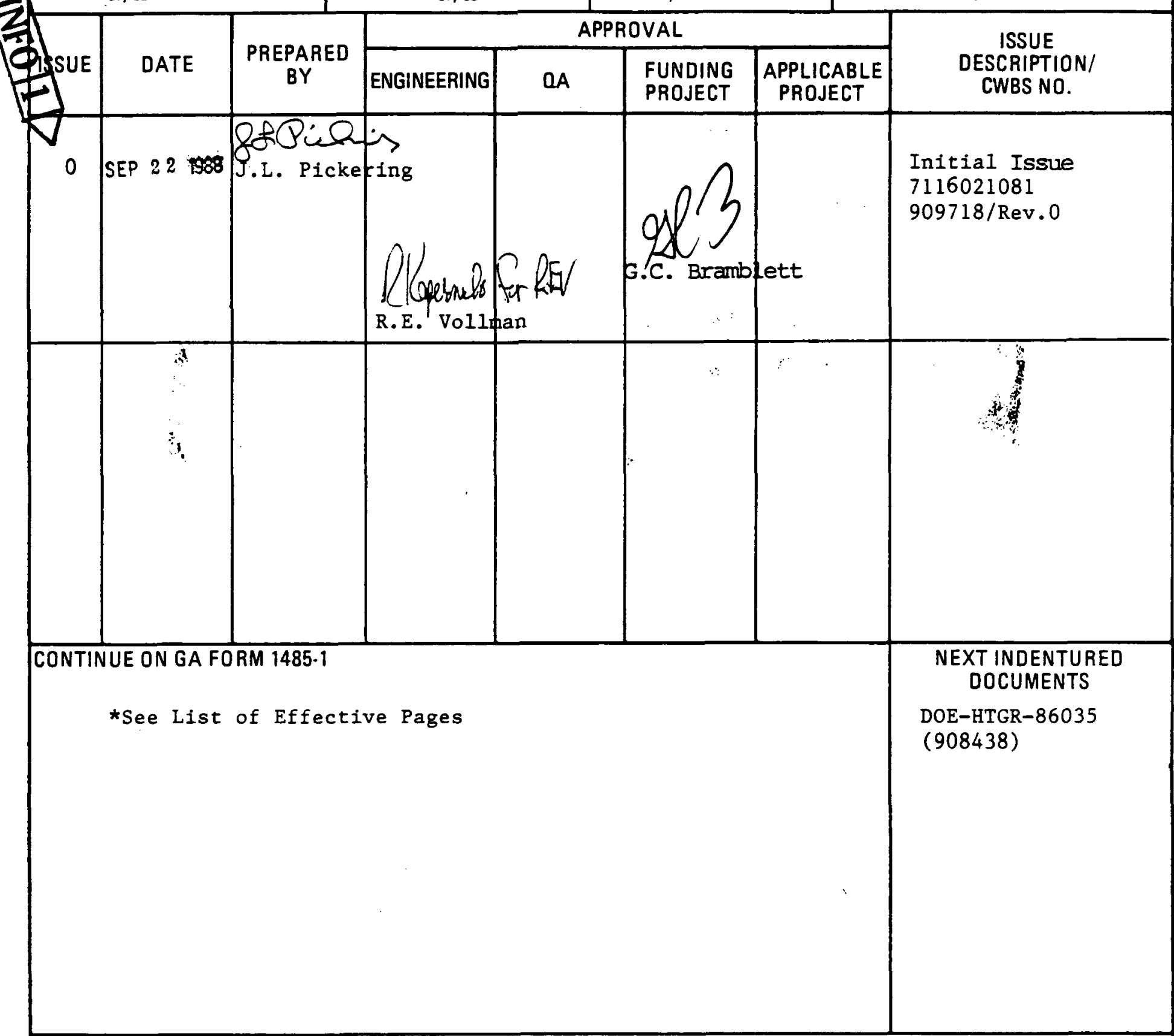

GA PROPRIETARY INFORMATION

THIS DOCUMENT IS THE PROPERTY OF GENERAL ATOMICS. ANY TRANSMITTAL OF THIS DOCUMENT OUTSIDE GA WILL BE IN CONFIDENCE. EXCEPT WITH THE WRITTEN CONSENT OF GA, (1) THIS DOCUMENT MAY NOT BE COPIED IN WHOLE OR IN PART AND WILL BE RETURNED UPON REQUEST OR WHEN NO LONGER NEEDED BY RECIPIENT AND (2) INFORMATION CONTAINED HEREIN MAY NOT BE COMMUNICATED TO OTHERS AND MAY BE USED BY RECIPIENT ONLY FOR THE PURPOSE FOR WHICH IT WAS TRANSMITTED.

$X$ NO GA PROPRIETARY INFORMATION 
IIST OF EFFECTIVE PAGES

Page Number

$i$ through $v$

$1-1$

2-1

3-1 through 3-2

4-1 through 4-2

$5-1$

6-1

7-1 through 7-7

8-1 through 8-13

9-1 through 9-2

10-1

Total Pages
Page Count

$\begin{array}{r}5 \\ 1 \\ 1 \\ 2 \\ 2 \\ 1 \\ 1 \\ 7 \\ 13 \\ 2 \\ 1 \\ \hline\end{array}$

36
Revision

0

0

0

0

0

0

0

0 
1. SUMMARY . . . . . . . . . . . . . . . 1-1

2. INTRODUCTION . . . . . . . . . . . . . . . . 2-1

3. TEST SPECIMEN CONFIGURATION . . . ........... 3-1

4. SPECIMEN MATERIAL ................... . . 4-1

5. FINITE ELEMENT MODEL ................ . . 5-1

6. MODEL LOADING ....................... 6-1

7. SPECIMENT CONFIGURATION STUDY RESULTS . . . . . . . . . 7-1

8. MODEL WITH ELLIPTICAL TRANSITION-LOADING RESULTS . . . . 8-1

9. CONCLUSIONS . . . . . . . . . . . . . . . . 9-1

10. REFERENCES . . . . . . . . . . . . . . . . 10-1

\section{FIGURES}

1. The reference biaxial stress test specimen configuration . - 3-2

2. Axisymetric finite element model of specimen with elliptical transition ................. 7-2

3. Normalized axial stress within gage length and at maximum stress locations - specimen with elliptical transition . . . 7-3

4. Axisymetric finite element model of specimen with a single 2 in. radius transition................. 7-4

5. Normalized axial stress within gage length and at maximum stress locations - specimen with single 2 in. radius transition ................. 7-5

6. Axisymetric finite element model of specimen with double 2 in. radius transition................ 7-6

7. Normalized axial stress within gage length and at maximum stress locations - specimen with double 2-1n. radius transition . . . . . . . . . . . . . . . . 7-7

8. Pressure loading condition at $I=5.015$ in. ........ 8-2

9. Pressure loading condition at $I=2.8665$. . . . . . . 8-3

10. Elliptical transition test specimen - tension only, axial stress $(0: 1)$. . . . . . . . . . . . . 8-4

11. Elliptical transition test specimen - internal pressure only, hoop stress $(1: 0) \ldots . . . . . . . . . . .48$ 


\section{FIGURES (Continued)}

12. Elliptical transition test specimen - tension + internal pressure loading, axial stress $(1: 1)$. . . . . . . . 8-6

13. Elliptical transition test specimen - tension + internal pressure loading, hoop stress $(1: 1)$. . . . . . . . . 8-7

14. Elliptical transition test specimen - compression only, axial stress $(0:-1)$. . . . . . . . . . . . 8-9

15. Elliptical transition test specimen - compression + internal pressure, axial stress $(1:-1)$. . . . . . . . . . 8-10

16. Elliptical transition test specimen - compression + internal pressure, hoop stress $(1:-1)$. . . . . . . . . . 8-11

17. Elliptical transition test specimen - $2 X$ compression + Internal pressure, axial stress $(1:-2)$. . . . . . . 8-12

18. Elliptical transition test specimen - $2 \mathrm{X}$ compression + internal pressure, hoop stress $(1:-2) . . . . . . . . .8-13$ 


\title{
1. SUMMARY
}

\begin{abstract}
A multiaxial test program is to be conducted by Oak Ridge National Laboratory (ORNL) on the core component graphlte. The objectives of the tests are to obtain fallure data under uniaxial and biaxial states of stress in order to construct a failure surface in a two-dimensional stress space. These data w1ll be used in verifying the accuracy of the maximum stress failure theory belng proposed for use in designing the core graphtte components.
\end{abstract}

Tubular specimens are proposed to be used and are either loaded axially and/or subjected to internal pressure. This report includes a study on three specimen configurations. The conclusions of that study indicate that an elliptical transftion geometry produces the smallest discontinuity effects.

Several loading combinations were studied using the elliptical transition specimen. The primary purpose is to establish the location of the highest stress state and its relation to the gage section for all of the loading conditions. The tension/internal pressure loading condition ( $1: 1$ ) indicated that the high stress area is just outside the gage section but still should be acceptable.

This work is performed by General Atomics (GA) under subcontract to ORNL. The task is listed under Work Breakdown Structure (WBS) 1602.1 .2 and Milestone 1602.1.01.02 due September 30, 1988. 


\section{INTRODUCTION}

The Modular High-Temperature Gas-Cooled Reactor (MHTGR) core is composed of hexagonal prismatic H-451 graphite blocks. The core graphIte blocks are subjected to high temperature gradients, neutron flux, and loads due to pressure, dead weight, and seismic events.

The maximum stress induced in the core graphite component is usually on the surface of a coolant hole, where a blaxial tensile stress field exists. However, when cracking of graphite web is hypothesfzed in the graphite criteria development, cracks may propagate to a location where the stress component parallel to the crack front is compressive. A biaxial fallure surface covering at least the first, second, and fourth quadrants is needed.

In the present conceptual and preliminary design phases, the failure surface defined by the maximum stress fallure theory is assumed to be a reasonable approximation for H-451 graphite under multiaxial state of stress (Assumption 1 in F2.1.2.1.2.2.4, "Protect the Capability to Maintain Fuel Element Structural Integrity"). The associated uncertainties need to be quantified and included in the development of probabilistically based stress criteria. A design data need (DDN M.10.18.1 in Ref. 1) has been prepared for verifying the above assumption.

In response to the $\mathrm{DDN}$, an experimental test program is being structured by ORNL in order to develop the multiaxial strength surface of H-451 graphite material. The test specimen configuration proposed by ORNI (Ref. 2) for use in that test program is analyzed in this report. The purpose of the analysis is to ensure that fallure occurs in the gage section of the test specimen. 


\section{TEST SPECIMEN CONFIGURATION}

The specimen size and configuration is more or less dictated by material variability and material availability with the intent of maximizing the number of specimens per log. Therefore, in order to obtain a reasonable number of specimens the maximum diameter of the specimen was limited by ORNL to 2 in.

A proposed test specimen configuration was presented by ORNL as shown in Fig. 1. The axis of the specimen is in the axial direction of the graphite billet. This is called the reference configuration. The transition is represented by an elliptical shape which theoretically should produce the minimum discontinuity effect. The specimen is composed of three pleces of graphite bonded together with an epoxy paste adhesive. The center section is H-451 graphite with a 2-1n. long gage section. The nominal wall thickness of the gage section is 0.125 in. The two end pieces are also taken to be $\mathrm{H}-451$ graphite for this study, however, they could be made of any comparable modulus graphite.

Two alternative specimen configurations were included in the study in order to gain a comparison and to optimize the specimen geometry. A single radius and a double radius transition were modeled. A 2 in. transition radius was selected for both specimens for this study. The specimen length was taken to be the same for all specimens in this study. 


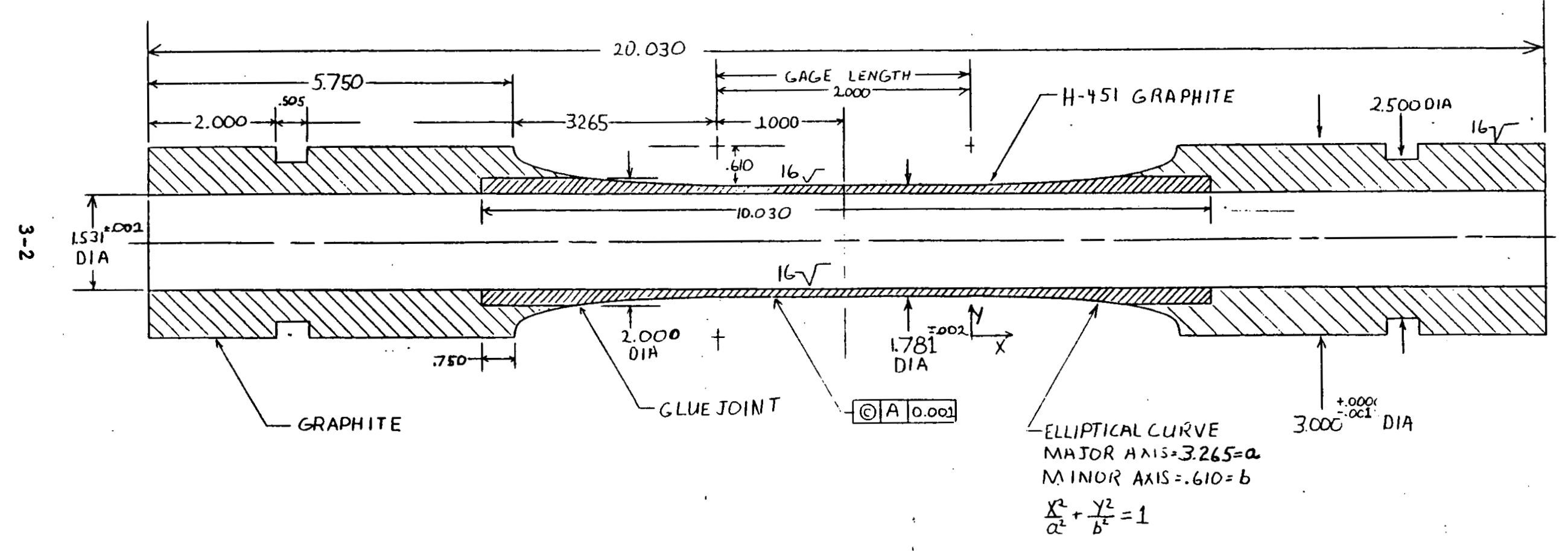

Fig. 1. The reference blaxial stress test specimen configuration (Ref, 2) 


\section{SPECIMEN MATERIAL}

Grade H-451 graphite is a near-1sotropic, petroleum-coke-based, artificial graphite developed specifically for MHTGR fuel element and reflector application by Great Lakes Carbon Company. The graphlte is produced from needle coke filler material, pitch binder, and additives processed to minimize impurity content. The graphite is manufactured by extrusion in the form of cylindrical logs resulting in a transversely isotropic material with one set of mechanical properties parallel and another set perpendicular to the axis of the log. As the axis of the finished fuel element coincldes with that of the $10 \mathrm{~g}$, the two material directions are usually referred to as axfal and radial, respectively. $\mathrm{H}-451$ is a near-1sotropic graphite, and the difference between the two material directions is not very large.

The strength of graphite, especially in tension but to a lesser degree also in compression, is much less uniform than that of the common metallic materials. The strength varles randomly from $\log$ to $\log$ and partly randomly, partly systematically within the log where the systematic part reflects a general increase in the strength away from the center. In local areas the structural characteristics are also affected by the grain size. Grade H-451 has a relatively coarse grain size of 0.0625 in. (maximum).

The multiaxial tests are to be performed at room temperature in air for the unfrradiated condition. The material properties used in the finite element model to represent H-45I graphite and the grip section were:

Elastic modulus, $E=1.2 \times 10^{6} \mathrm{ps} 1$, isotropic assumption Poisson's ratio, $=0.12$ 
The material properties used to represent the structural epoxy paste adhesive were:

Elastic modulus, $E=0.83 \times 10^{6} \mathrm{ps} 1$, 1sotropic assumption

Polsson's ratio, $=0.12$

The modulus property was taken from a technical data sheet of a high-modulus, high-strength, structural adhesive produced by Sika Corporation, name brand Sikadur 31, Hi-Mod Gel. 


\section{FINITE ELEMENT MODEL}

The ANSYS Computer Code (Ref. 3) was used in the analysis of the test specimen with the use of PATRAN (Ref. 4) as a pre- and postprocessor. The finite element model used geometric symetry cutting the specimen in half at the midlength. A relatively fine mesh was used in the gage section ( 1 in. long gage section - considering the symetry assumption used in the modeling) having four elements through the thickness, producing a $0.0313 \times 0.0313 \mathrm{in}$. grid. The epoxy paste adhesive layer was modeled having a thickness of 0.015 in. The elliptical shaped specimen model incorporated 1095 nodes and 928 elements. 
6. MODEI LOADING

The specified loading ratios (clrcumferential-to-axial) imposed on the model are:

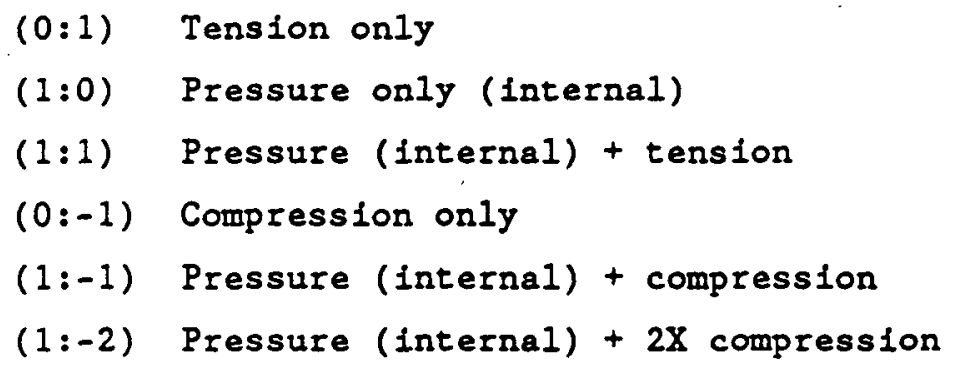

A tension/compression load of $1000 \mathrm{lb}$ was applied to the specimens at the slip ring groove location (Fig. 1). This produces a uniform tensile/compressive stress of $1538 \mathrm{psi}$ in the $0.125 \mathrm{in}$. thick cylindrical wall gage section. An internal pressure of 250 ps 1 was applied to induce an average wall hoop tension stress of 1540 psi in the gage section.

ORNL is presently proposing a rigld load-train fixture for the uniaxial load application similar to that of Ref. 5. A primary concern in using this kind of apparatus is specimen alignment. The reference document was very successful in controlling the alignment stress and it is recommended that the test fixture be built to the same tolerances. It is also recommended that a well strain-gaged thin walled, low modulus metallic specimen be used to establish the as-built alignment induced stress. 


\section{SPECIMEN CONFIGURATION STUDY RESULTS}

The finite element models and stress ratio results of the different specimen configurations studied are presented in Figs. 2 through 7 . A tension only loading condition was used for this exercise. The "reference" elliptical transition configuration produced a maximum stress ratio of 1.006 at 0.78 in. away from the symetry boundary condition (within the 1 in. gage section) as shown in Fig. 3. Therefore, for the tension only case, fallure would be expected in the gage section.

The single 2 in. radius specimen model is shown in Fig. 4. The corresponding tensile load results are presented in Fig. 5. A uniform stress distribution is shown at the 0.0 and 1.1059 in. locations (the two curves are superposed on each other). The maximum discontinuity location occurs at $2.8975 \mathrm{in}$. away from the symetry boundary condition at a value of 1.07 .

The double 2 in. radius specimen model is shown in Fig. 6. The corresponding tensile load results are presented in Fig. 7. The maximum discontinuity location occurs at 1.7629 in. away from the symetry boundary condition at a value of 1.12 .

The elliptical shaped specimen produced the minimum concentration effect at the geometry discontinuity boundary in the tension loading case. The maximum concentration occurring in the gage section. Therefore, the elliptical transition specimen shall be used to investigate the effects for the speclfied load ratios. 
$909718 / 0$

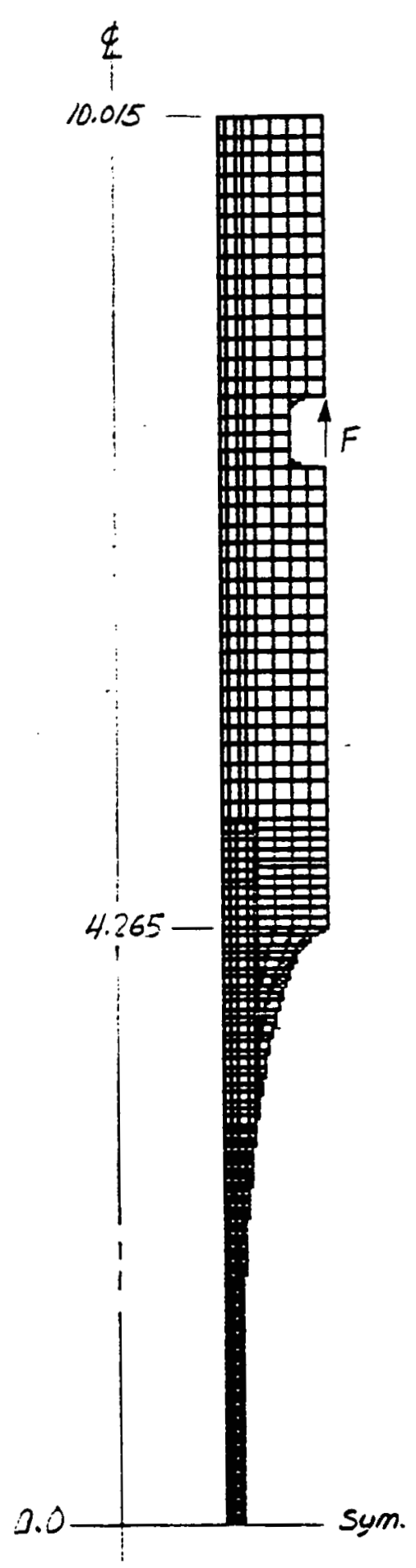

Fig. 2. Axisymetric finite element model of specimen with elliptical transition 


\section{AXIAL TENSION ONLY}

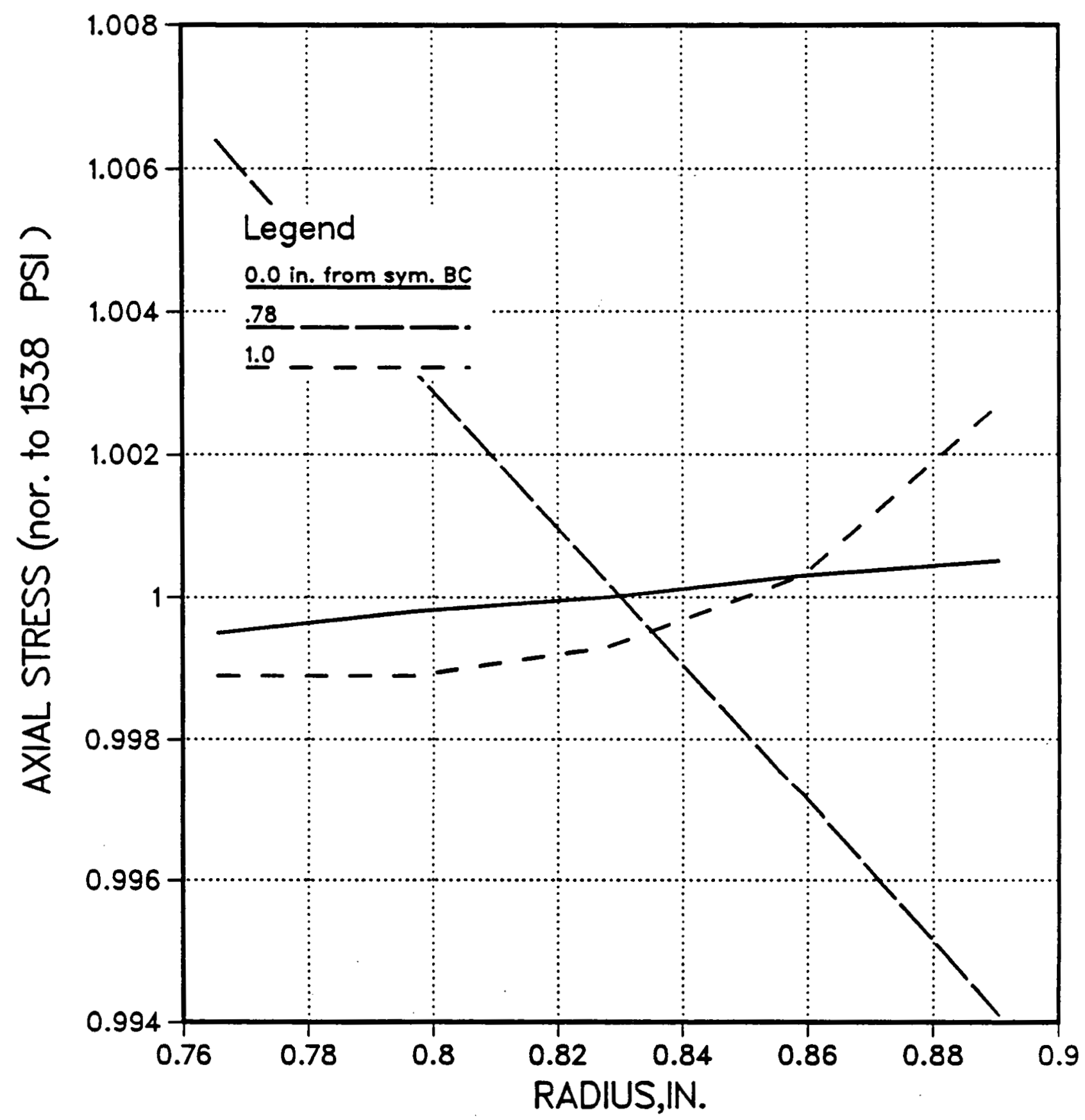

F1g. 3. Normalized axial stress within gage length and at maximum stress locations - specimen with elliptical transition 


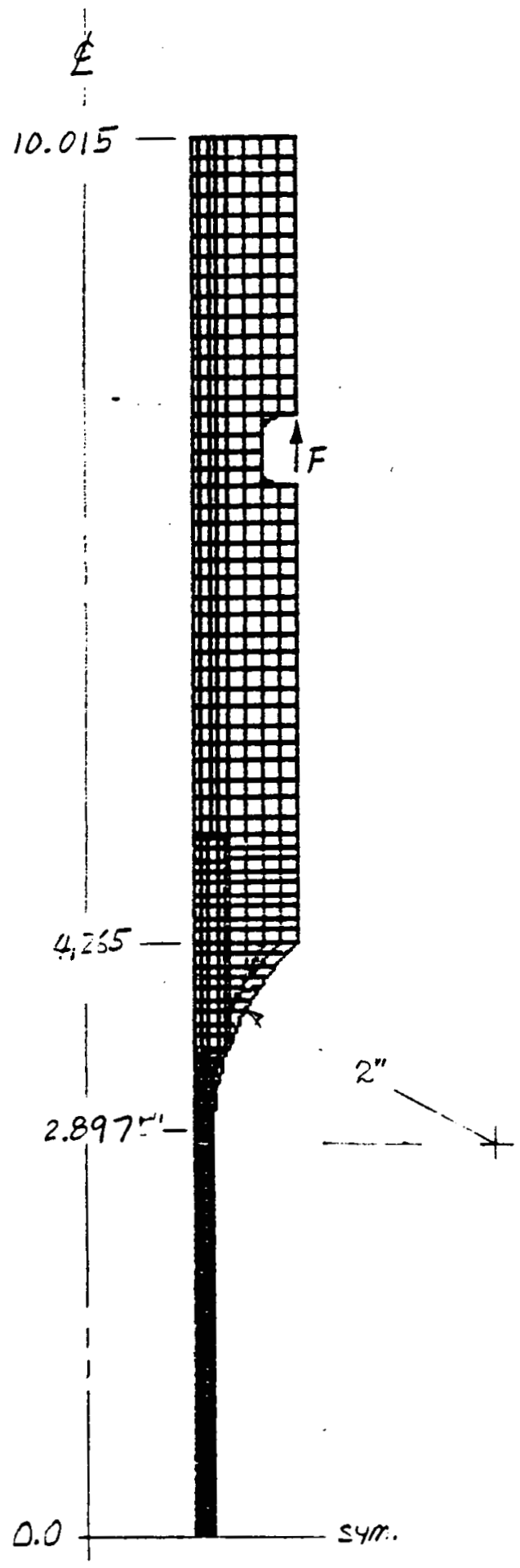

Fig. 4. Axisymetric finite element model of specimen with a single 2 in. radius transition 


\section{SINGLE- 2" RADIUS - TENSION ONLY}

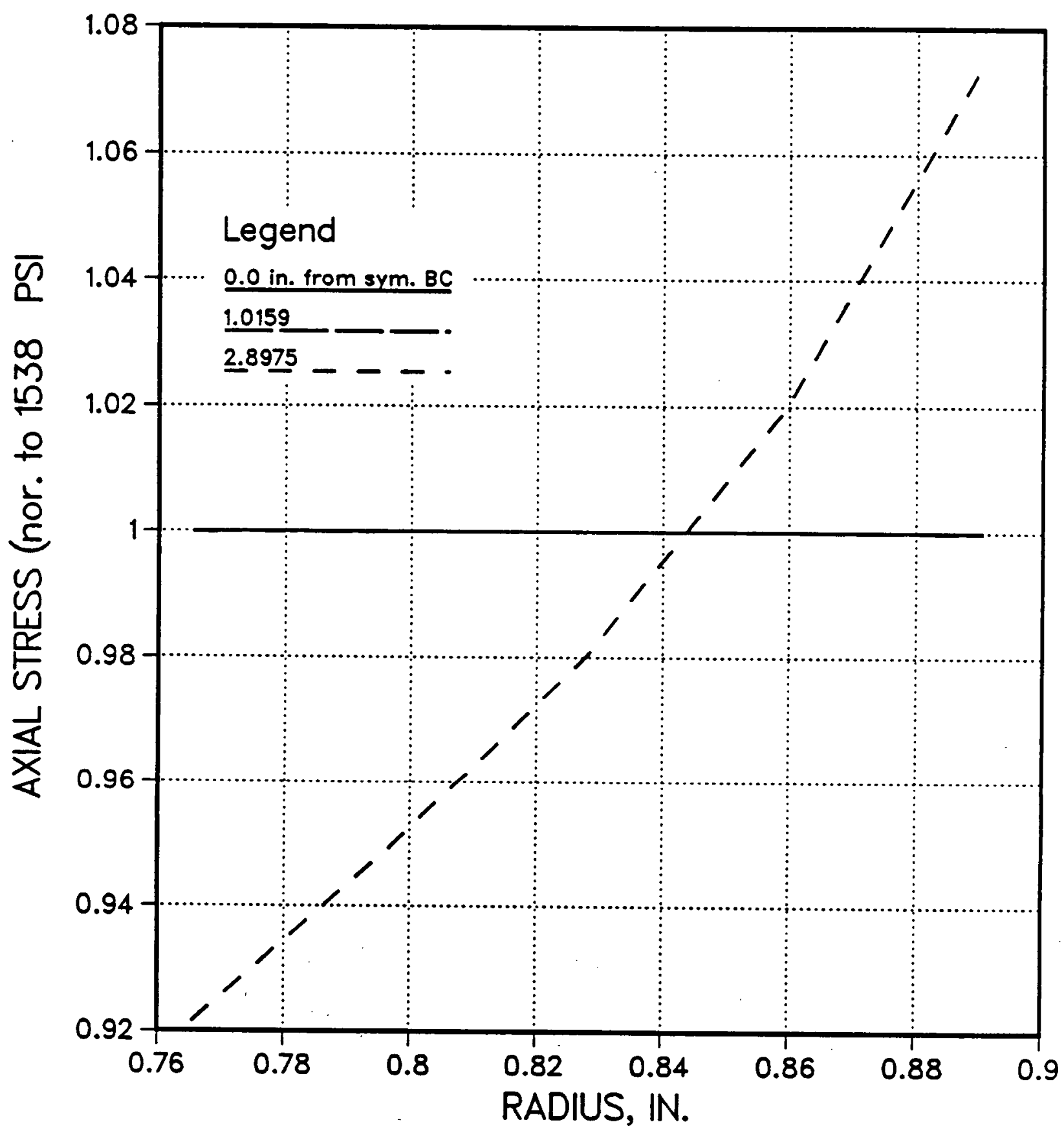

Fig. 5. Normalized axial stress within gage length and at maximum stress locations - specimen with single 2 in. radius transition 
$909718 / 0$

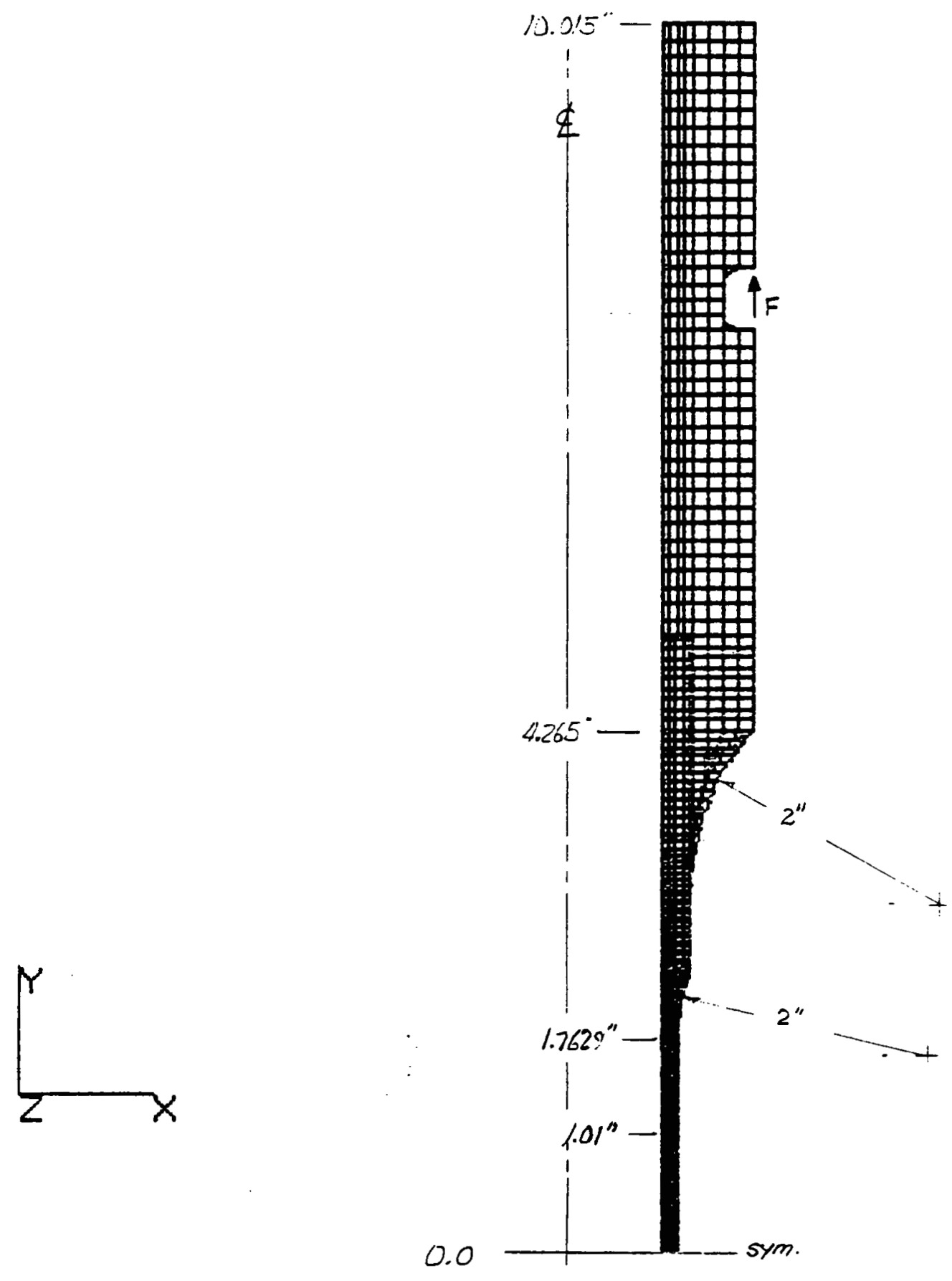

Fig. 6. Axisymetric finite element model of specimen with double 2 in. radius transition 


\section{DOUBLE - 2" RADIUS - TENSION ONLY}

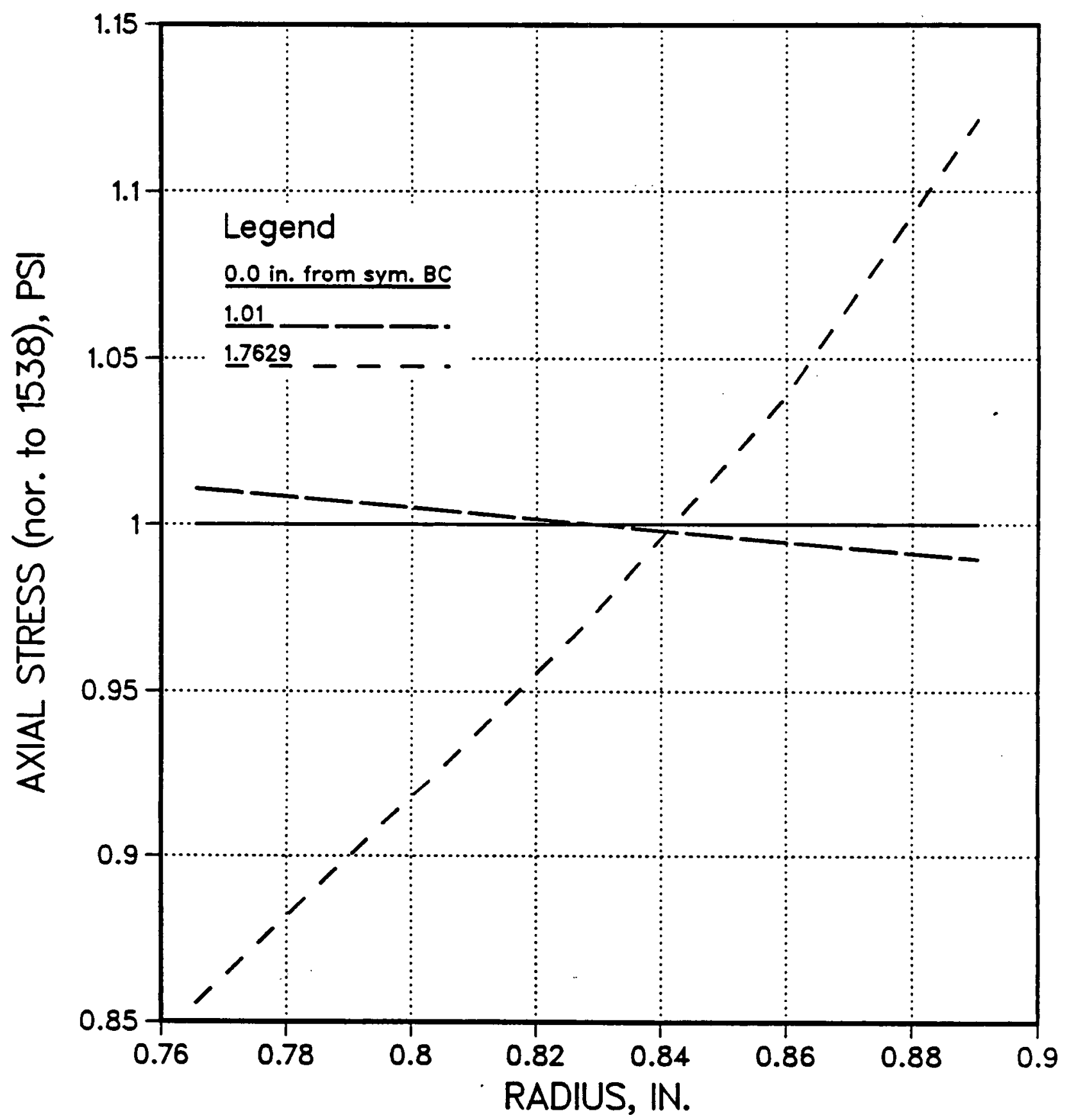

Fig. 7. Normalized axial stress within gage length and at maximum stress locations - specimen with double 2 in. radius transitio. 


\section{MODEL WITH ELIIPTICAL TRANSITION-LOADING RESULTS}

Two internal pressure loading distributions were applied on the reference elliptical shaped specimen as shown in Figs. 8 and 9 . The two loading conditions produced very simllar stress results indicating that the surface area on which the internal pressure is applied is not crit1cal. It is not recommended, however, to apply pressure to a region smaller than that shown in Fig. 9 because high axlal bending stresses could be developed at the pressure boundary (outside the gage section).

The developed axial stress under tension loading $(0: 1)$ is presented in Fig. 10. The highest axial stress occurs within the gage section, as reported in Fig. 3, however, the next highest occurs outside the gage section (on the outer surface). The maximum developed axial stress in the adhesive layer was less than $600 \mathrm{psi}$. The gage section axial stress state at the symetry boundary is also presented in Fig. 10 (1538 psi).

The developed hoop stress under internal pressure loading $(1: 0)$ is presented in Fig. 11. The highest stress occurs within the gage section ( 0.0 to $1 \mathrm{in.})$. The delta stress through the wall (250 ps 1 ) is indicative of a thick wall effect of $1 P$. The average wall hoop tension stress of $1540 \mathrm{psi}$ in the gage section is also presented.

The developed axial and hoop stress under the combined tension and pressure loading $(1: 1)$ are presented in Flgs. 12 and 13. Although the discontinuity effect of the elliptical transition is relatively small, it is large enough to produce the maximum surface stress state outside the gage section in both the axial and hoop direction. The average stress in the axial direction is maximum in the gage section, the average stress in the hoop direction is a maximum outside the gage section. 


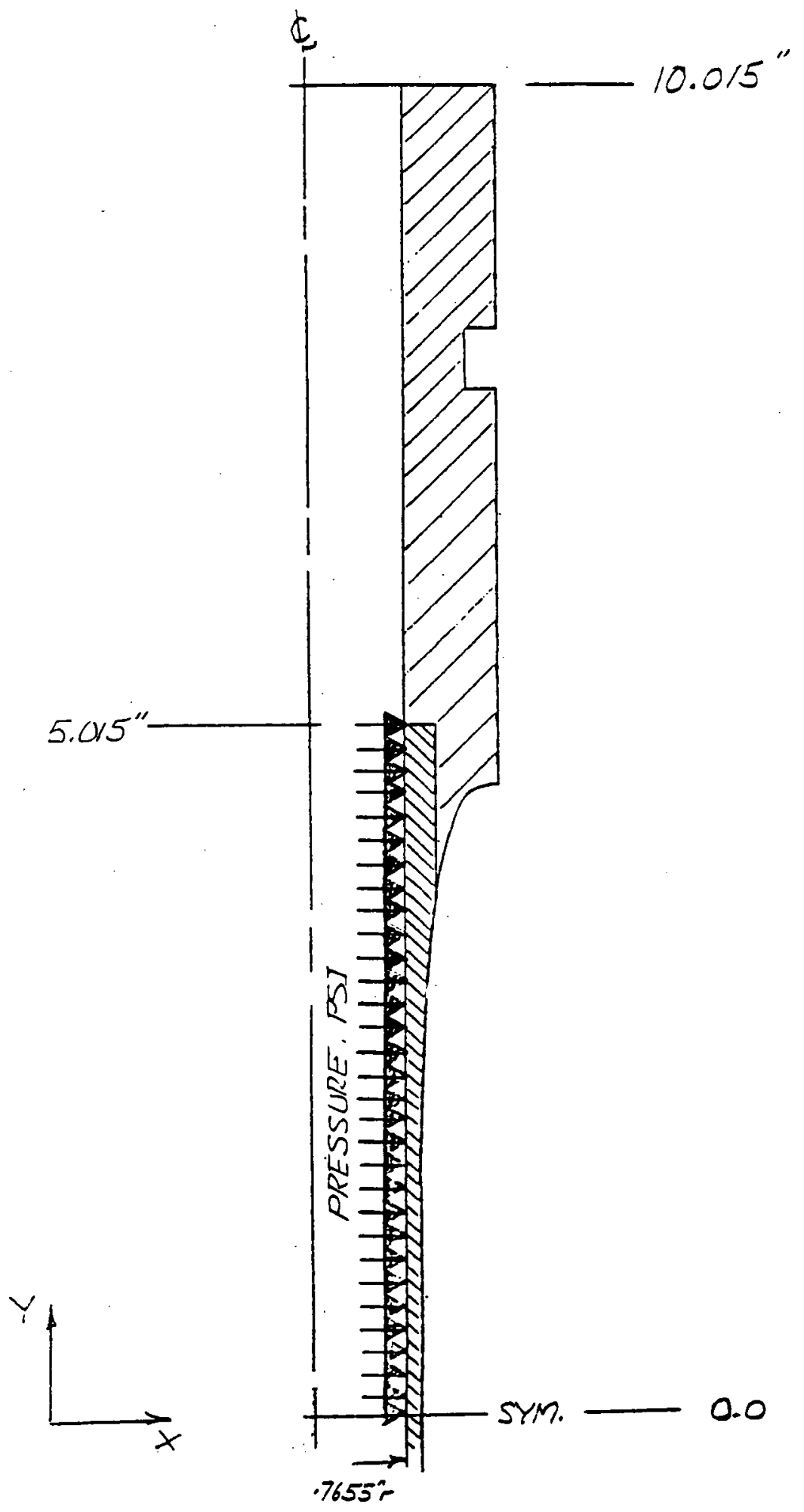

Fig. 8. Pressure loading condition at $L=5.015 \mathrm{in}$. 


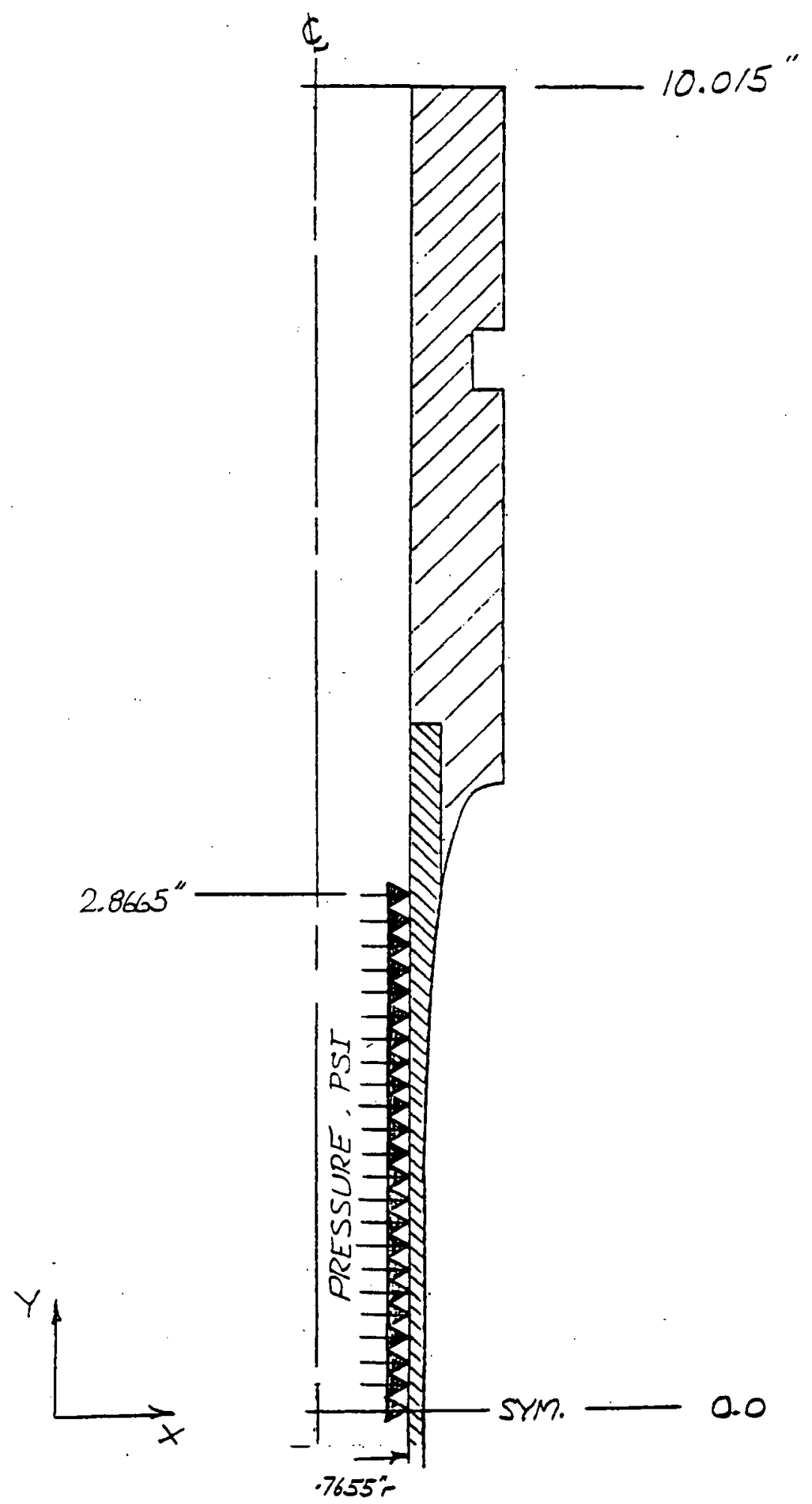

F1g. 9. Pressure loading condition at $L=2.8665$ 


\section{AXIAL STRESS - TENSION ONLY}

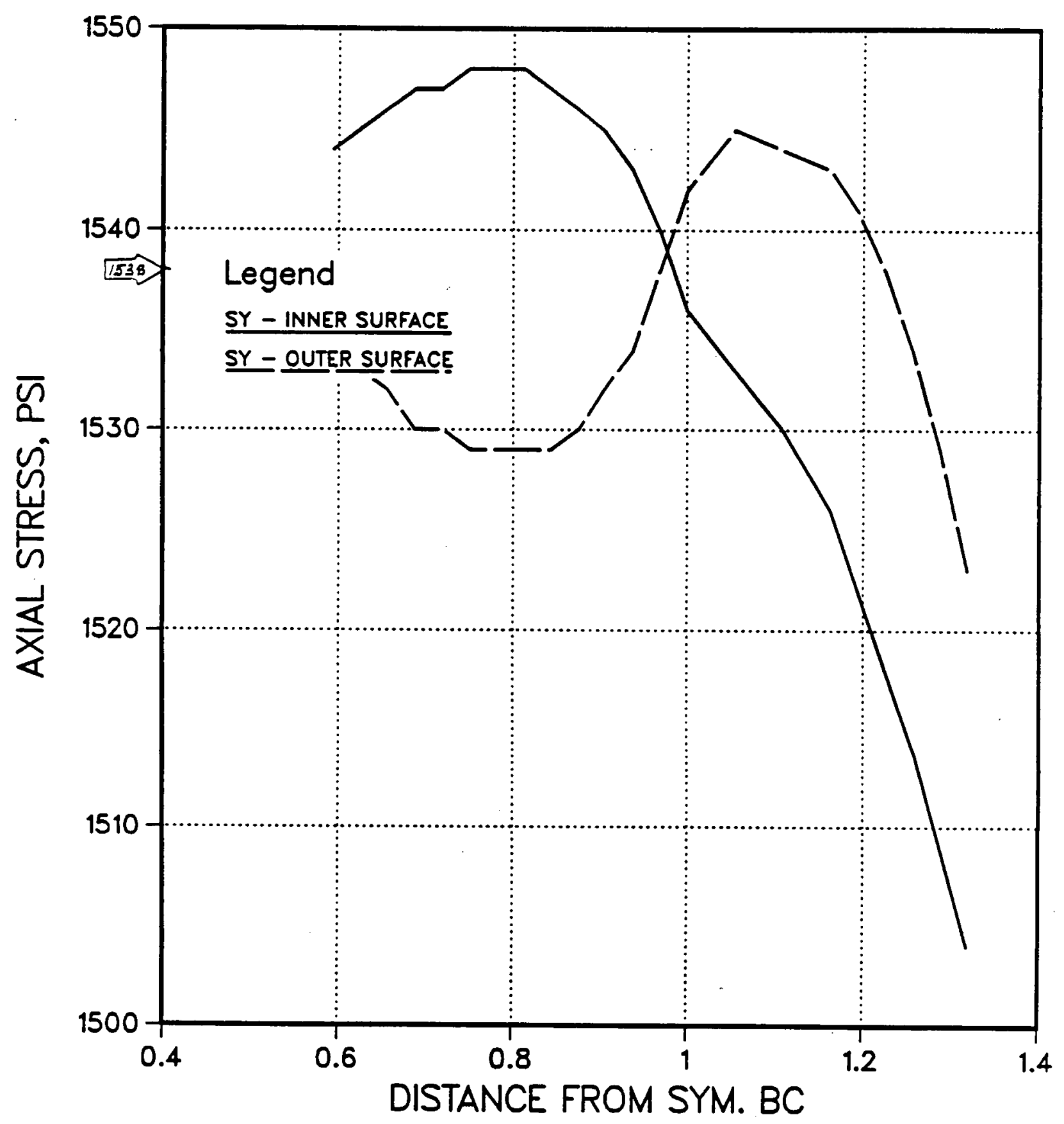

Fig. 10. Elliptical transition test specimen - tension only, axial stress $(0: 1)$ 


\section{HOOP STRESS - PRESSURE ONLY}

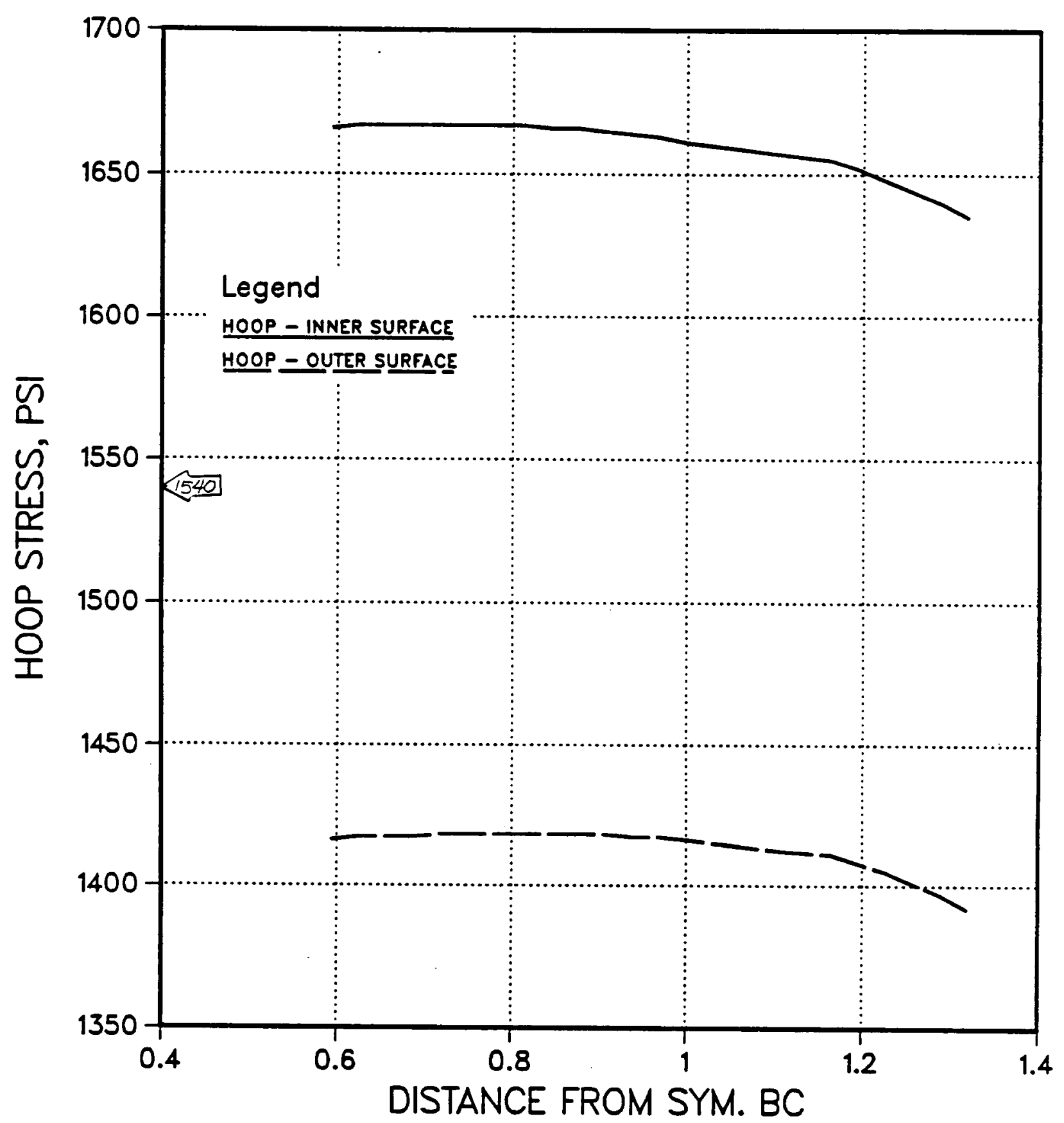

Fig. 11. Elliptical transition test specimen - internal pressure only, hoop stress $(1: 0)$ 


\section{AXIAL STRESS - TENSION + PRESSURE}

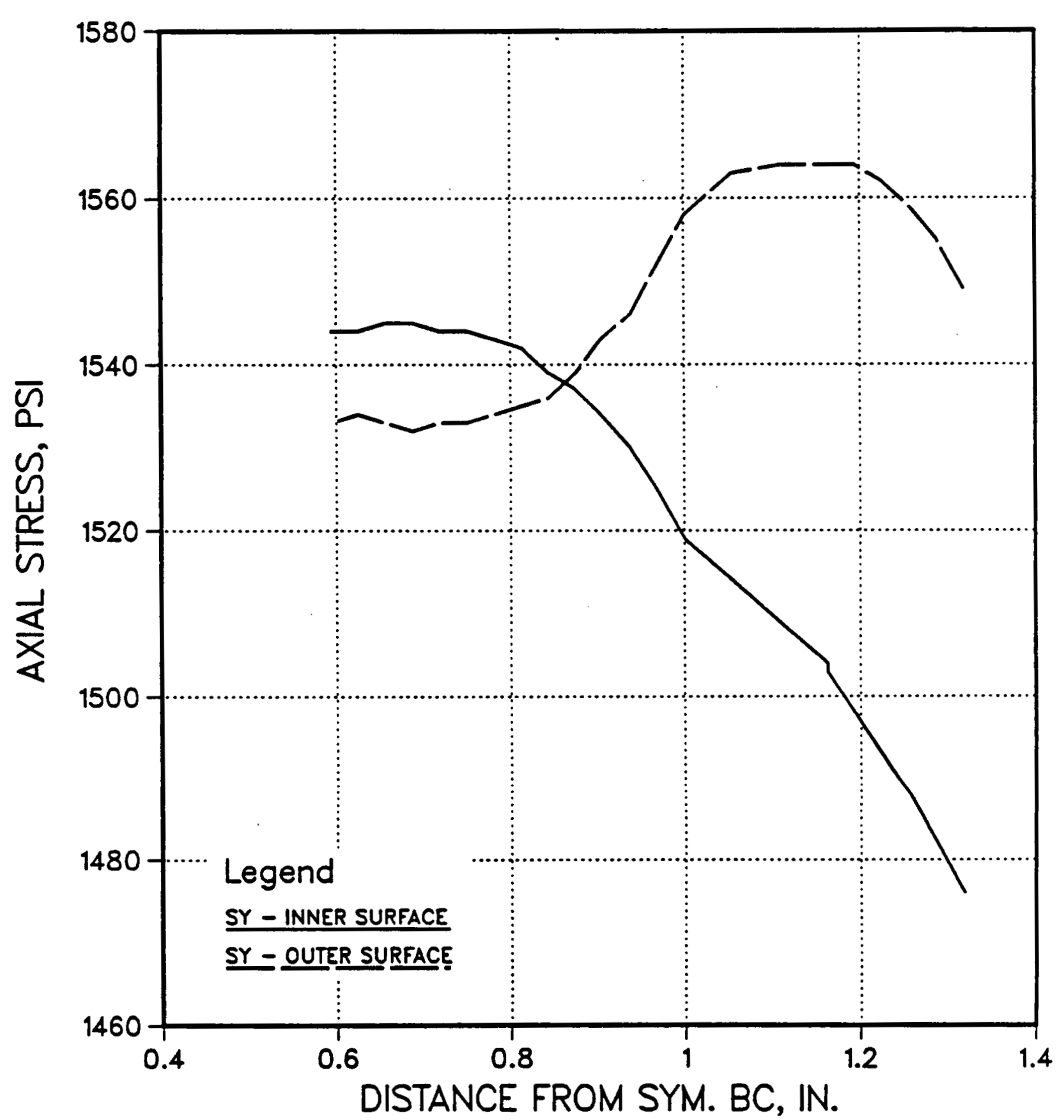

\footnotetext{
Fig. 12. Elliptical transition test specimen - tension + Internal pressure loading, axial stress $(1: 1)$
} 


\section{HOOP STRESS - TENSION + PRESSURE}

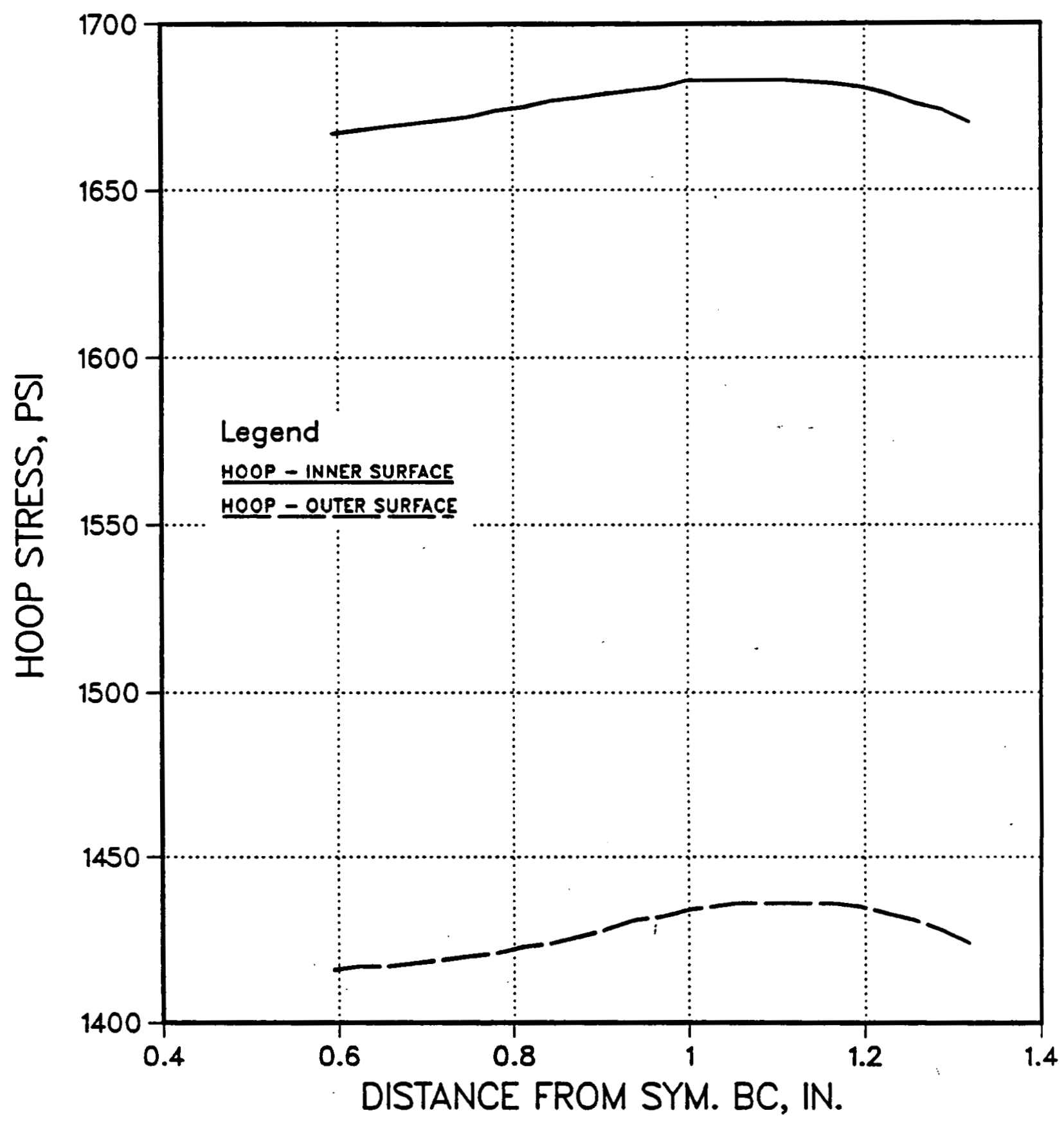

Fig. 13. Elliptical transition test specimen - tension + internal pressure loading, hoop stress $(1: 1)$ 
The developed axial stress under compression loading $(0:-1)$ is presented in Fig. 14. The axial stress distribution is the inverse of the axial tension loading case (Fig. 10), as expected.

The developed axial and hoop stress under combined compression and internal pressure loading $(1:-1)$ is presented in Figs. 15 and 16 . Both the axial and hoop direction stress results indicate that the maximum stress occurs within the gage section.

A compressive load higher than that used for the tension case will be required on the specimen in order to induce failure. The higher load is required because graphite has a higher strength in compression than in tension. Therefore, an internal pressure $+2 X$ compression $(1:-2)$ loading condition was applied on the model. The developed axial and hoop stress is presented in Figs. 17 and 18. The results indicate more of a concentration of the maximum stress in the gage section than in the $(1:-1)$ loading case (Figs. 15 and 16). In a brittle materlal, a buckle mode of failure is very difficult to distinguish from a compressive failure. The specimen configuration, however, using an elastic analysis indicates that the geometry is stable. 


\section{AXIAL STRESS - COMPRESSION ONLY}

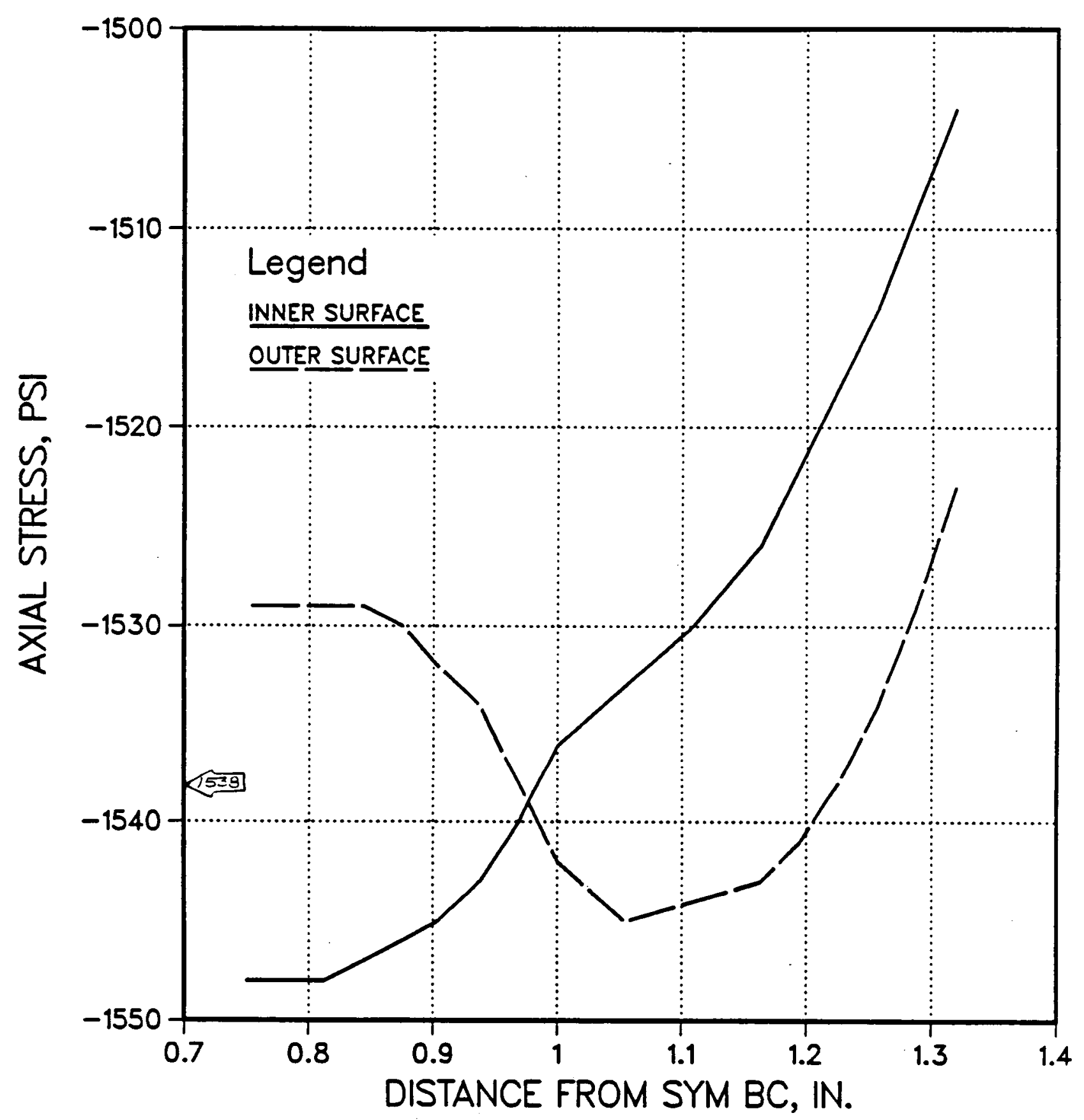

Fig. 14. Elliptical transition test specimen - compression only, axial stress $(0:-1)$ 


\section{AXIAL STRESS - COMPRESSION + PRESSURE}

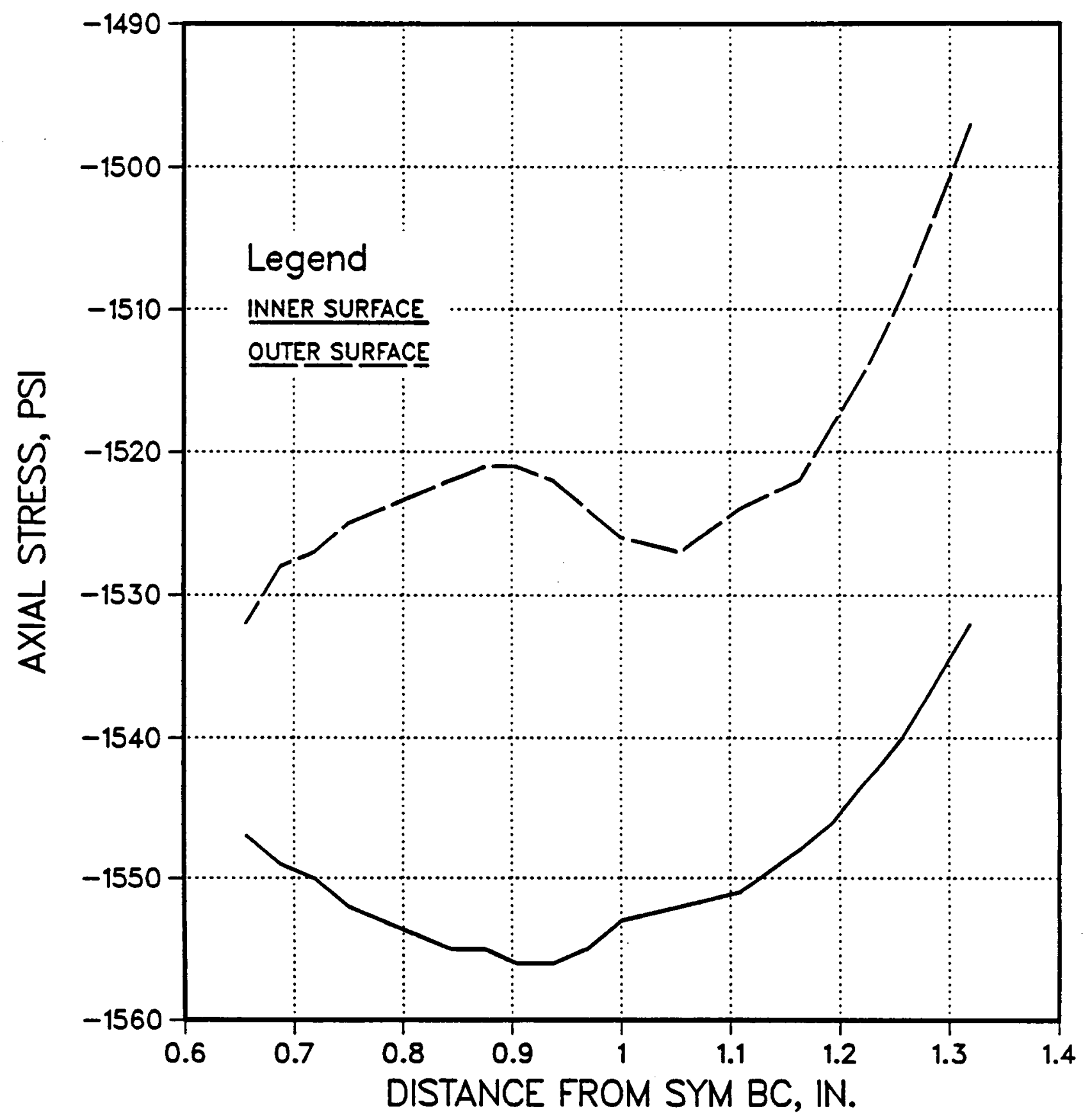

Fig. 15. Elliptical transition test specimen - compression + internal pressure, axial stress $(1:-1)$ 


\section{HOOP STRESS - COMPRESSION + PRESSURE}

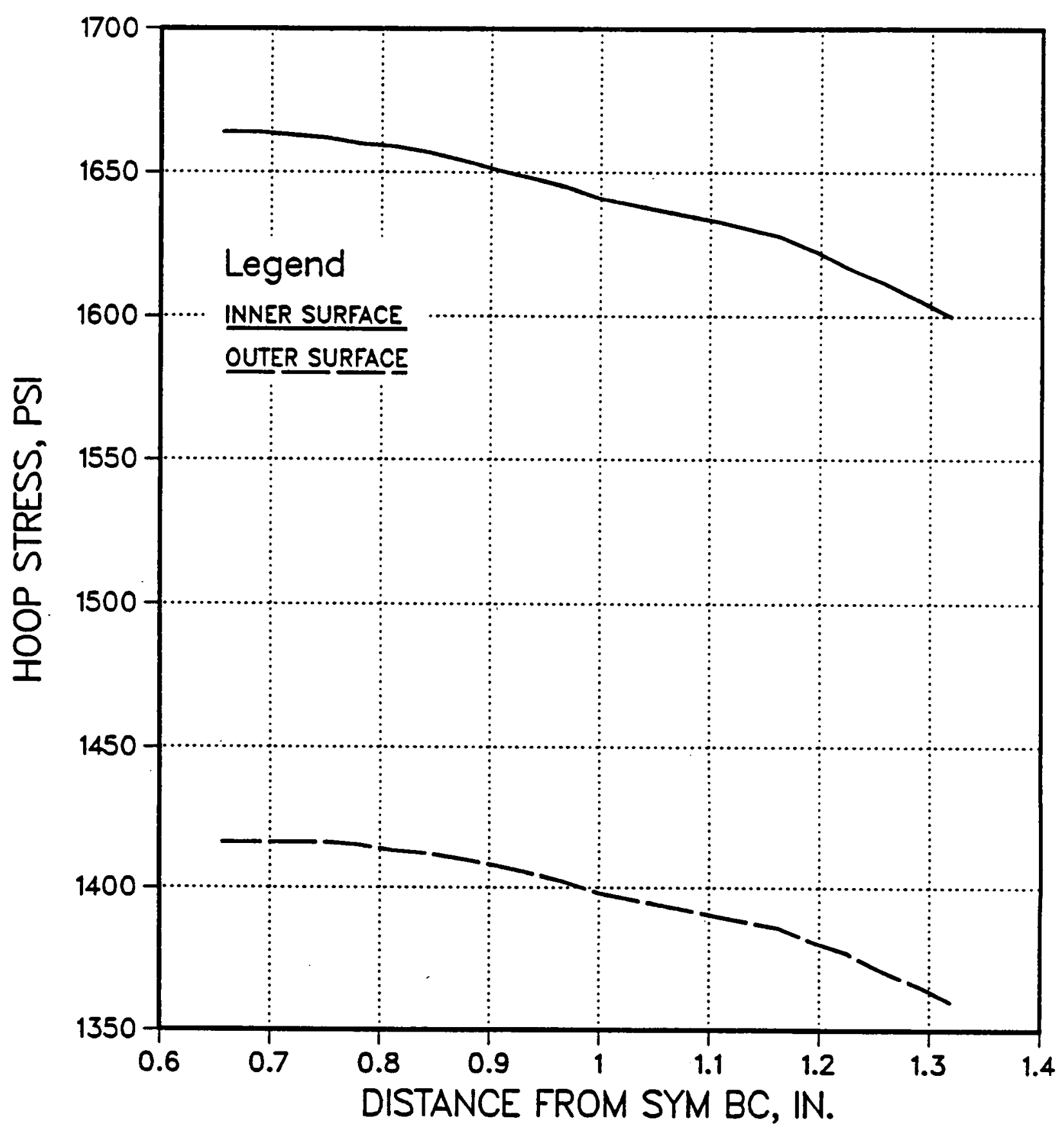

Fig. 16. Elliptical transition test specimen - compression + internal pressure, hoop stress $(1:-1)$ 


\section{AXIAL STRESS - 2X COMP. + PRESS}

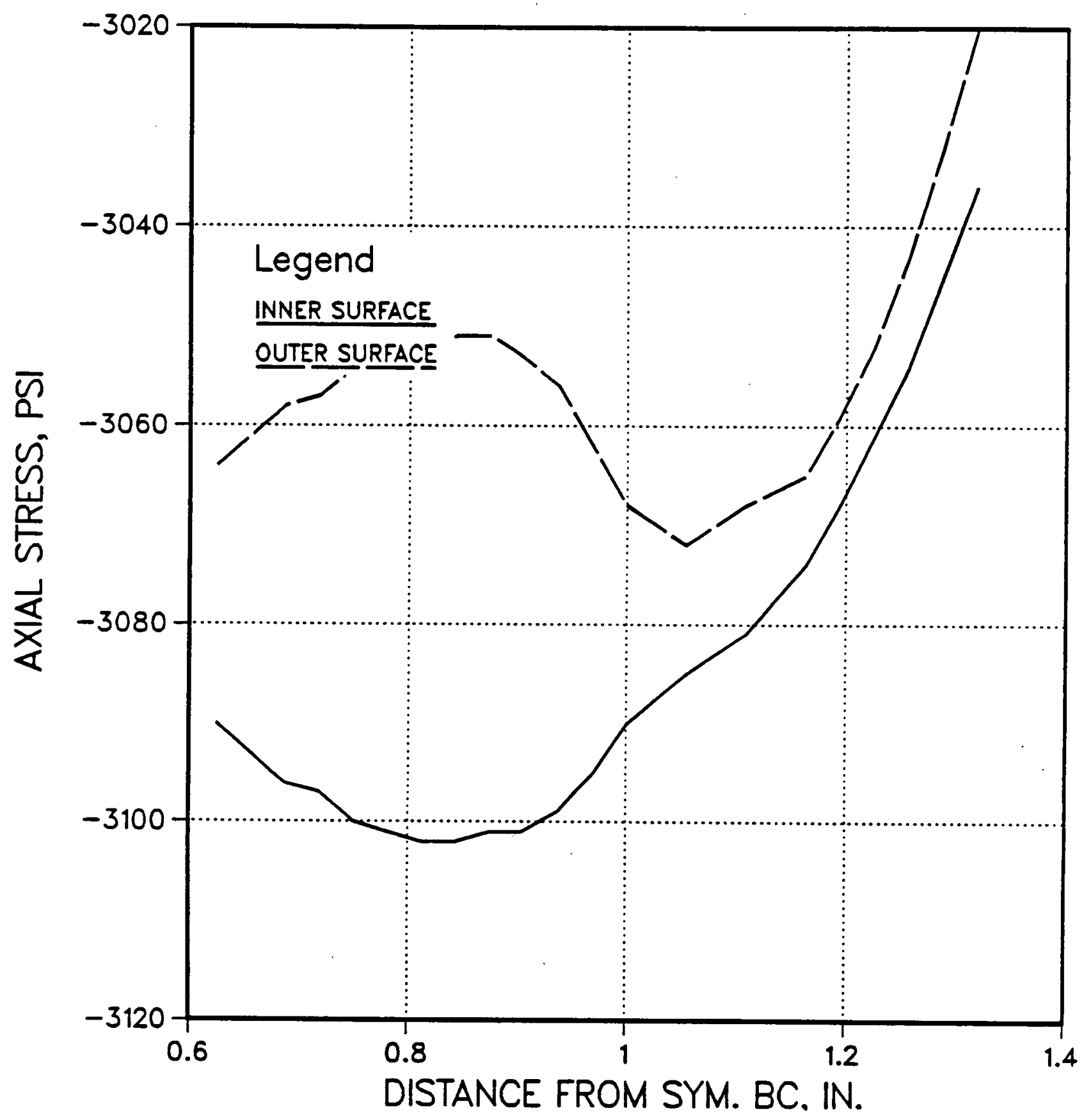

Fig. 17. Elliptical transition test specimen - $2 \mathrm{X}$ compression + internal pressure, axial stress $(1:-2)$ 


\section{HOOP STRESS - $2 X$ COMP. + PRESS}

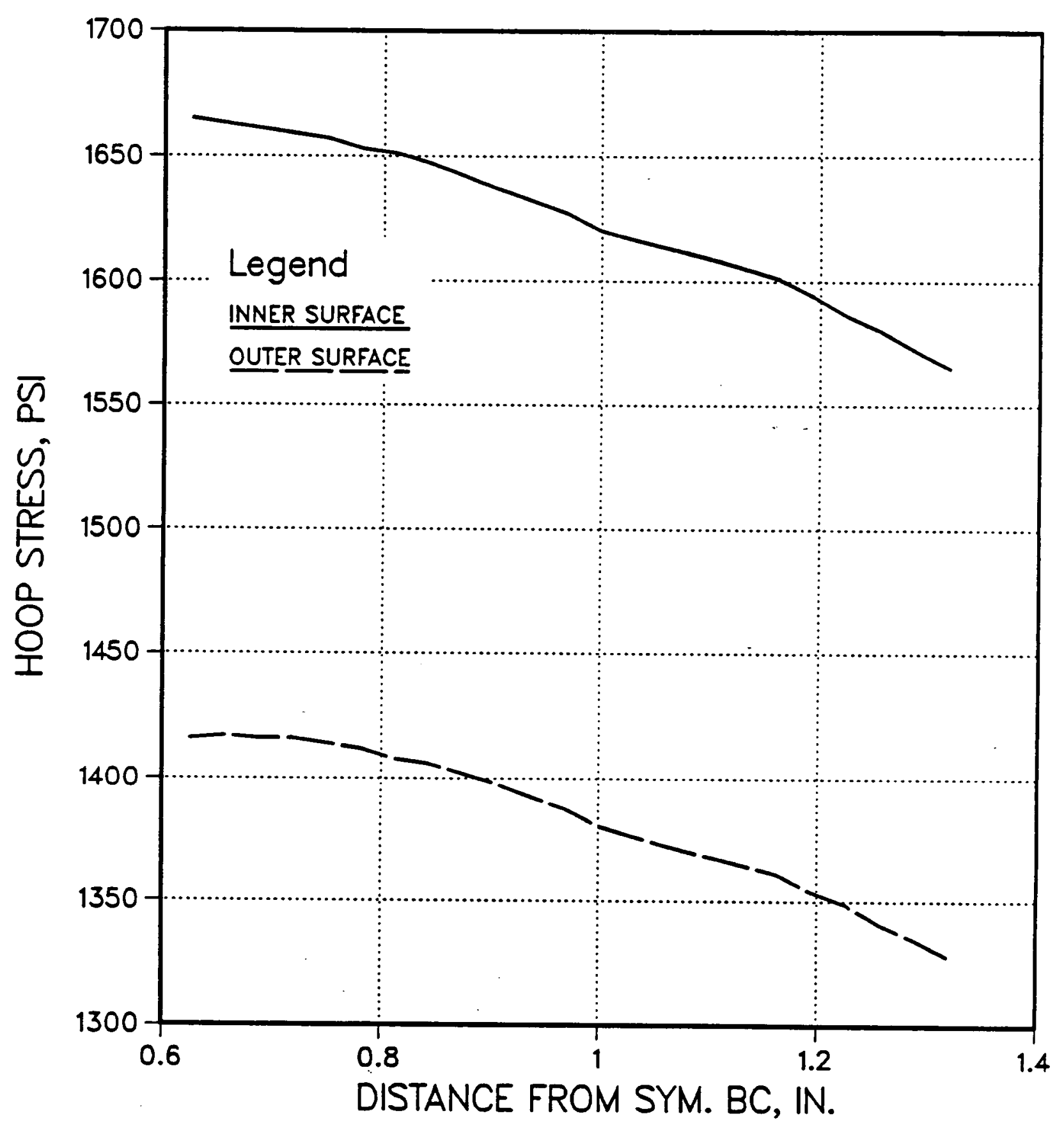

Fig. 18. Elliptical transition test specimen - $2 \mathrm{X}$ compression +
internal pressure, hoop stress $(1:-2)$ 


\section{CONCLUSIONS}

Of the three specimen configurations studied the elliptical transition specimen proposed by ORNL illustrated the lowest discontinuity effects under an axial tension loading condition. The elliptical transition specimen was, therefore, selected for further study using the proposed loading combinations.

In order to obtain a reasonable number of specimens out of a graphite $\log$ the specimen outside diameter was 1 imited by ORNL to $2 \mathrm{in}$.

The specimen loading ratios used in this study were selected to describe the predominate points of the fallure surface of H-451 graphite. More load comblnations might be required in order to completely define the surface.

The stress state in the epoxy paste adhesive did not exceed 600 psi for the axial tension loading case. The technical data sheet for the material indicated a tensile strength capacity over 3000 psi.

The bladder used to pressurize the specimen should be long enough such that the pressure boundary does not induce axial bending in the gage section. The minimum length should be about 3 in. (from the symmetry boundary) per Fig. 9 .

The maximum stress condition occurred within the gage section for most of the loading ratios studied. The one exception was for the tension + pressure loading case (1:1). The average stress is maximum within the gage section for the axial direction, however, the maximum outer axial surface stress occurs just outside the gage section (Fig. 12). The maximum hoop stress also occurred outside the gage length (Fig. 13). The maximum stress in both the axial and hoop 
directions are felt to be close enough to the gage section to be acceptable.

If the maximum stress location of load case (1:1) is not acceptable the only recommendation would be to suggest a specimen configuration having symetry on both sides of the wall of the specimen. This geometry is recognized as being quite difficult to machine with the outside diameter limited to 2 in.

The average stress in the end piece is no more than $25 \%$ of that in the gage section. A parametric study was not performed in the grooved region (load application point), however, the model studied did not produce a tensile stress over 1000 psi (based on a corner radius of 0.120-in. and a point load on the outside node).

The overall strength characteristics of this specimen could be affected by the thin-walled configuration. That is, the specimen might not reach the graphite strength capability because of the grain size effect. The nominal wall thickness in the gage section is approximately two grains thick (at 0.0625 in. per grain). This phenomena should be investigated before the start of the multiaxial test program. A suggested approach would be to test thin-walled and solid circular cross section specimens having equal areas. 


\section{REFERENCES}

1. "Design Data Needs Modular High-Temperature Gas-Cooled Reactor," Issued by General Atomics, DOE-HTGR-86-025, Rev. 2, March 1987.

2. Martin Marletta Energy Systems Drawing D-SR-BAGS-1.

3. "ANSYS - Englneering Analysis System," Issued by Swanson Analysis Systems, Inc., Version 4.3, June 1987.

4. "PATRAN PLUS User Manual," Issued by PDA Engineering, P/N-2191001, July 1987.

5. "A Comparison of Methods For Testing Graphites In Uniaxial Tension," Issued by Douglas Missile and Space Systems Division, Douglas Report DAC-62112, Apr11 1968. 